\title{
Inequality of Languages and the Question of Choice in Translation
}

\section{Debarshi Nath}

\begin{abstract}
The paper looks at the practice of translation in the context of the continuing cultural-linguistic hegemony of the West. Drawing on insights presented by Talal Asad and Prasenjit Gupta, the paper looks at the different manifestations of inequality that are obvious in the process of translation. The paper contends that translation studies as a discipline must take into account the socio-political context of literature and engage in greater self-reflexivity. Finally, the paper pleads for an ethical turn in translation practices.
\end{abstract}

Keywords: translation, politics, globalization, language, power

This paper examines the act of translation in the Indian context against the backdrop of issues of power and the culturallinguistic hegemony of the West. It is now accepted that though we live in a world of competing truths aided by the internet and the media, there is a greater consciousness and even, resistance to the explicitly Western as well as exclusive nature of academic thought. This paper, however, should not be seen as an attempt to look at the West uncritically as a homogenous entity nor is it a plea to discard all that is Western. The writer is aware of the fact that the West in itself can never be a monolithic entity and also that there is a lot that the West has offered us in terms of values and principles which we continue to live by and adore, such as secularism and democracy. The argument in this paper needs to be seen more against the limited backdrop of the practices of translation that are in vogue in our country right now. In this context, it is particularly appropriate to consider the effects of linguistic inequality on the process of translation. Taking into 
account the agency of the translator, the choice of texts and the search for equivalence is an ideological issue. While there can be no prescription regarding the choice of texts or equivalents, I do believe that an analysis of translation trends brings to the fore the politics of appropriation of ideas for extra-academic gains. In fact, the trend of translation at a given point of time reflects the hegemonic tendencies that are at work.

Before I begin, let me make explicit my ideological footing. I am a teacher of cultural studies and thus by virtue of my disciplinary standing, I am concerned with the inequality of power that pervades different cultural practices and as a person committed to justice and equity in the world, I find it necessary to begin my paper by asking some fundamental, if not rudimentary questions about translation. What is the relationship of translation with ideology, politics and power? What purpose did translation serve in the colonial times? How has globalization impacted translation practices? To what extent will the inequalities of power, resources and technologies lead to a situation where translation will lead to a unidirectional adoption of Western or dominant international standards by people all over the world? Considering the given situation, what, if any, are the ethical responsibilities of the translator?

Let me start off by looking at the past. When we look back at the late 18th and 19th centuries, the encounter with the West resulted in a complex, relatively bidirectional, culturalintellectual relationship between India and the West. In the fields of science, engineering, and in new disciplines such as politics and economics, English was the donor language for translations into Indian languages. In the fields of philosophy, religion and linguistics, Sanskrit assumed the role of donor language for translations into English and other European languages. By 1820, all the major universities of Europe had a space for Sanskrit studies and it came to enjoy immense prestige. Some of the greatest thinkers of the 19th and early part of the 20th centuries were, by their own admission, deeply influenced by Indian thought - 
Humboldt, Hegel, Goethe, Kant, Nietzsche, Ferdinand de Saussure, Roman Jakobson (Sareen, 2010; 78). The situation has changed in recent times. While there have been numerous translations within and into Indian languages, the dominant trend has been of translations from European languages into modern Indian languages, and these too chiefly from English. This has become a unidirectional flow, leading to the emergence of a recipient-donor relationship. Notwithstanding the growth of postcolonialism as a theory of import in recent times, modern Indian languages "have been placed in a recipient role with European languages, particularly English as the donor. There is in this trend an implicit recognition of the source language as the intellectual reservoir along with an acceptance of the relatively impoverished state of the target language" (Kapoor, 1995: 20). This trend is a reflection of what Kapoor calls "a part of the general attitude of uncritical subordination to the western ideas" (1995: 20).

I think there is hardly any dispute today about the imbalance of power in the relationship between languages. This being the case, the linguistic inequalities at work when texts are translated from 'lesser' languages like Assamese into more 'rich' languages like English, is something that needs to be looked at. Following Talal Asad, Prasenjit Gupta (1998: 172) identifies three kinds of linguistic inequalities: 'political', 'surface' and 'deep' inequalities.

1. 'Political inequality' refers to the imbalance of linguistic power arising out of the economic power of the US and of English.

2. 'Surface' inequalities is about differences in size of vocabulary, grammar, syntax, phonology, and surface features; 'surface inequalities', include the relative sizes of languages. This imbalance between source and target vocabularies has obvious implications for lexical choices made in translation and their stylistic and other effects. The differences in vocabulary size also have implications for linguistic lending and borrowing: words are more likely to travel from English into Assamese than the other way around. The bottom line 
is that in all kinds of transactions the weaker language is transformed more than the stronger. Following Lawrence Venuti (2004: 42), retaining 'foreignness' in translated texts has almost become a matter of principle - a question of political correctness, in so far as translations into English are concerned. What happens to the question of retaining 'foreignness' in a text when texts are translated into the regional languages? In translation between European languages, native words can be retained without any fear of obfuscation. Repeated use of words like zeitgeist, déjà vu in English provide examples of this.

3. 'Deep' inequalities are about differences in the internal workings of different languages. Asad's category of 'deep' inequalities is related to Walter Benjamin's concise analysis of the differences between languages in terms of 'mode of intention' in 'The Task of the Translator' (2000: 18): the words 'pain' and 'dukh' (Assamese) may "intend" the same object but the 'mode of intention' may be different. This, in turn, is related to Spivak's use of the three-tiered notion of language (as rhetoric, logic, silence) in 'The Politics of Translation' (2000: 399):

She (the translator) must be able to confront the idea that what seems resistant in the space of English may be reactionary in the space of the original language (2000:404).

It is the particular interactions among these various attributes of language that differ from one language to another, which cannot easily be reproduced in translation. This is linguistic inequality at the most fundamental, most innate, most difficultto-verbalize level (and characteristics of language exist in ways that cannot be communicated, they exist outside language itself). This inequality of language which exists outside language is what Asad refers to as deep inequalities and it is this form of inequality that is the most politically vibrant.

Asad talks of the political power of languages: "because the languages of Third World societies ... are "weaker" in relation 
to Western languages (and today, especially to English), they are more likely to submit to forcible transformation in the translation process than the other way around ... Western nations have the greater ability to manipulate (Third world countries) ... Western languages produce and deploy desired knowledge more readily than Third World languages do (1986: 157).

This reminds us of the debate between Krishna Kanta Handique and Kaliram Medhi, the then president of the Assam Sahitya Sabha regarding the propriety of translating texts from English into Assamese (2001: 98). While Handique, a renowned scholar, thought that translation at that point of time in history was a preparatory process leading to the final flowering of Assamese literature, Medhi felt that translation would be the harbinger of the intrusion of 'alien' thoughts and ideas into native culture.

However, at this point of time I would like to distance myself from Asad and Sareen's argument and admit that it would be a fallacy to refer or treat the West as a homogenous entity churning out "dangerous" texts readily swallowed by gullible readers from India. But I do contend that examination of translation trends that prevail during specific periods brings about an understanding of the larger cultural forces at work. Indian theoreticians like Tejaswini Niranjana have taken up this issue really well to highlight the ways in which translation figured prominently in the project of orientalism (1922:2):

Translation as a practice shapes, and takes shape within, the asymmetrical relations of power that operate under colonialism. What is at stake here is the representation of the colonized, who need to be produced in such a manner as to justify colonial domination, and to beg for the English book by themselves.

Tejaswini Niranjana highlights the interpellative (in the Althusserian sense) aspect of colonial translation projects. In fact, as she rightly argues, translation was effectively used as a tool for the creation of "willing" colonial subjects in the texts of orientalists 
like William Jones.

Let us take up an example of the present state of affairs in the translation scenario of Assam. I believe that most Assamese readers are aware of the fact that today, on an average, a Dale Carnegie translation sells better than most books written in Assamese. Why do such self-help books sell so well? Is this trend a manifestation of a new system of values?

James English, author of The Economy of Prestige (2005), amply demonstrates that "the global market for cultural prestige" will "impose its increasingly transnational system of values" and thereby shift both monetary and symbolic success and energy away from the local stage and make forms valuable "only to the degree that they may be repackaged or recontextualized for mainstream consumption" (quoted in lyer and Zare, 2009: xxvi). Thus in this age, profit-motive and political correctness decide many of the policies of the publishing houses.

It is painfully obvious that the so-called 'global marketplace' is a Western-dominated place: it is clear that only a tiny percentage of non-English original works trickle slowly into English translations, and even then are much more likely to be circulated if deemed immediately user-friendly to Western readers (xxvii).

Many works of the regional literatures of India have not received the promotion and larger audience they deserve even within, let alone outside of, India. Iyer and Zare (lyer and Zare, 2009: xxvii) cite the example of Indira Goswami (also known as Mamoni Raisom Goswami), the Assamese writer who is probably the most well known outside Assam. In spite of this, Indira Goswami is yet to be an internationally visible writer and this is proved by lyer and Zare on the basis of their analysis of the copies of her books available at the World Cat database.

Thus, given the inequality between the languages, it is important to keep in mind that the West has the larger share of 
'truths' in the world. To return to Talal Asad once again:

The translation is addressed to a very specific audience, which is waiting to read about another mode of life and to manipulate the text is read according to established rules, not to learn to live a new mode of life (ibid 159).

There are instances when translators have tried to forcefully fit a foreign word into a native context or consciously or subconsciously appropriated a foreign word for other interests. Consider the case of the almost unthinking use of the word 'tribe' which has nearly entered the vocabulary of the regional languages. We are aware that anthropologists like Lewis Morgan subscribed to the 19th century view of tribe as representing not only a particular type of society but also a particular stage of evolution. It worked best where the tribe was in fact an isolated, self-contained, and socially homogeneous group to a large extent, but this was not the case everywhere. The problem assumed a chronic form in South Asia, where tribes had cohabited and shared space with other types of social formations for centuries. The officially approved "Scheduled Tribe" skirts the issue of a formal definition and merely stands for a set of communities listed in an official schedule.

To cite another example, while today there is a recognition of the translator as fully engaged in the literary, social and ideological realities of his or her time, what has often been missing from translation studies accounts is a clear definition of what "culture" means. While "culture" is recognized as one of the most difficult and over determined concepts in the contemporary human and social sciences, it often appears in translation studies as if it had an obvious and unproblematic meaning (Simon, 1996:x).

Translators are generally aware that he/she must understand the culture that informs the text; in fact, it is said, and rightly so, that texts are "embedded" in culture. Thus, it is argued that the more "embedded" a text is, the more difficult it is to translate. However, this is where we get into a problem; to quote 
Sherry Simon

The difficulty with such statements is that they seem to presume a unified cultural field which the term inhabits; the translator must simply track down the precise location of the term within it and then investigate the corresponding cultural field for corresponding realities. What this image does not convey is the very difficulty of determining "cultural meaning" (1996: 130).

In India, for example, the term 'sanskriti', which translates as 'culture', is emblematic of a system of representation that calls 'Indian culture' into being. Here, "the culture question is an intimate part of the formation of a national(ist) modernity, but culture in modernity tends to be represented as something that remains outside of modernity" (2007: 211). In other words, while the idea of nation is a gift of modernity, the idea of a civilizational (traditional) culture is evoked to counter modernity (Nath and Dutta, 2012: 12). It would be well to remember that the translation of culture as 'sanskriti' happened at a definite moment in history: it was the product of a nationalist discourse that tended to depict the East as the source of spiritual culture and the West as the source of material or scientific Western culture.

Thus, translation studies needs to problematize the understanding of concepts such as culture and tribe. Secondly, translation studies must also be made accountable for the confusion surrounding such terms today. Rudolf Pannwitz makes a very pertinent observation regarding the need for translators to test the tolerance of their language for incorporating unaccustomed forms:

Our translations, even the best ones, proceed from a wrong premise. They want to turn Hindi, Greek, English into German instead of turning German into Hindi, Greek, English. Our translators have a far greater reference for the usage of their own language than for the spirit of the foreign works. ... The basic error of the translator is that 
he preserves the state in which his own language happens to be instead of allowing his language to be powerfully affected by the foreign tongue. Particularly when translating from a language very remote from his own he must go back to the primal elements of language itself and penetrate to the point where work, image, and tone converge. He must expand and deepen his language by means of the foreign language. (quoted in Benjamin, 2000:22)

But this is easier said than done. It is largely something the translator cannot determine by individual activity (any more than the individual speaker can affect the evolution of his or her language) - it is governed by institutionally defined power relations between the languages/modes of life concerned.

The issue of translation is also related to the status of English in India. Is English an Indian or a foreign language? Though the use of English has grown exponentially in India over the last few decades, it is indubitable that it is not the language of the majority. Questions remain regarding the ethos of the language. There is a strange irony at work here: on the one hand we say that English is an Indian language but we cannot seem to manage without translation of English.

I believe that the agency of the translator and the tremendous political potential of the act of translation are accepted facts today. In this context, is translation from English into Indian languages an attempt to undo historical wrongs? Is this a part of a postcolonial civilizing mission? Is it a reflection of the plains man's burden? Having said this, "Harish Trivedi (1997) has demonstrated how Premchand's translation of Anatole France's Thais was a political act in the sense that the very selection of the text was of one which was not part of the literature of the colonial power and that it attempted a sort of liberation of Indian literature from the tutelage of the imperially-inducted master literature, English" (quoted in Ketkar).

So to conclude, translation helps to create and maintain 
cultural hierarchies. Translation obviously contributes to the ability of different groups of people to understand each other. But, while translation can definitely go a long way in bridging the gap between cultures and languages within India and beyond, even in ideal circumstances it cannot function as the ever-preferred alternative. More and more works of translation are welcome, but the economic and political might of a few nations can and will ensure that only certain books and films in certain languages are available to a global citizenry. Already we are well on the path of wiping out indigenous languages of the world. In such a situation, translation can be both a threat as well as a blessing for "minority" languages. "Translation into a dominant monoculture such as English can lead to an eventual situation of fewer works being composed in tongues other than English" (Nalini and Zare, 2009: $X X X)$. In such a case, we will be involved in the task of figuratively reconstructing the monolingual mythical tower of Babel once again.

To conclude,

The global dominance of English has been accompanied by a growing demand for translation, as people's own language continues to be the preferred language for access into informational goods. Translation is not just important in quantitative terms, it is also key to understanding current processes of cultural globalization, which are characterized by inequality and asymmetry (Bielsa, 2009: 14).

In such a scenario, translators as individuals and as groups are ethically responsible for, different uses of translation. Translators therefore need to adopt a more self-critical approach to translation. The need of the hour is "to facilitate cultural interface that is multidirectional rather than oriented to the unilateral dissemination of Westernized cultural forms, thus displacing local cultural forms elsewhere in the world, translators must be realistic about the material conditions of translation and cultural exchange under globalization" (Tymoczko, 2009: 183). The exchange of culture is never free of material interests. China 
has been able to resist and counter the threat of unidirectional flow of knowledge, in which, the East very often finds itself in the receiving end. Apparently, Chinese readers do not have to wait very long to have access to the latest inventions, discoveries and advances in the field of research in any language of the world. To cite an example, when I randomly surfed the net for Chinese translation agencies, I discovered 299 such in a single website (http://www.translationdirectory.com/translation_agencies_in_ china.php ). This indicates that on an average even the relatively less-educated Chinese have more ready access to the current pool of knowledge than the Indians.

\section{REFERENCES}

Asad , Talal. 1986. 'The concept of Cultural Translation in British Social Anthropology' in James Clifford and George E. Marcus (eds.) Writing Culture: The Poetics and Politics of Anthropology, London: University of California Press.

Benjamin, Walter. 2000. 'The Task of the Translator' in Lawrence Venuti (ed.) The Translation Studies Reader. London and New York: Routledge.

Bielsa, Esperanza. 2009. 'Globalization, Political Violence and Translation: an Introduction' in Experanza Bielsa and Christopher W. Hughes (eds.) Globalizations, Political Violence and Translation. New York, Palgrave Macmillan.

Gupta, Prasenjit. 1998, 'Post-or Neo-Colonial Translation? Linguistic Inequality and Translator's Resistance' in Translation and Literature, Vol. 7, No.2. (1998), pp. 170-193.

Handique, Krishna Kanta. 2001. 'Anubador Katha' in Krishna Kanta Handiqor Rachana Sambhar, Guwahati: Assam Sahitya Sabha.

Iyer, Nalini and Bonnie Zare. 2009. Other Tongues: Rethinking the Language Debates in India. New York: Rodopi.

Kapoor, Kapil. 1995. 'Loss, Recovery and Renewal of Texts in India's Tradition'. Lecture in the Department of Sanskrit, Sagar University, Sagar. URL: http://www.infinityfoundation.com/indic_colloq/ 
papers/paper_kapoor3.pdf. Accessed on 31.05.15.

Ketkar, Sachin. 'Literary Translation: Recent Theoretical Developments'

URL:http://www.translationdirectory.com/article301.html Accessed on 25/02/2011.

Nath, Debarshi Prasad and Juri Dutta. 2012. 'Women and Culture in India: Countering the Force of Nativity' in South Asian Cultural Studies Vol 4. No. 1 pp 12-18.

Niranjana, Tejaswini. 1992. Siting Translation: History, PostStructuralism, and the Colonial Context. Oxford: University of California Press.

Niranjana, Tejaswini. 2007. 'Feminism and Cultural Studies in Asia'. Interventions: International Journal of Postcolonial Studies, Vol 9, No. 2. pp. 209-218.

Sareen, Santosh K. 2010. 'Translation in India: History and Politics' in Traducao \& Comunicacao, No 20 (2010).

URL: http://sare.unianhanguera.edu.br/index.php/rtcom/article/ view/1964/877

Accessed on 25/02/2011.

Simon,Sherry. 1996, Gender in Translation: Cultural identity and the politics of transmission. London and New York Routledge.

Spivak, Gayatri. 2000, 'The Politics of Translation' in Lawrence Venuti (ed.) The Translation Studies Reader. London and New York Routledge.

Tymoczko, Maria. 2009, 'Translation, Ethics and Ideology in a violent Globalizing world' in Experanza Bielsa and Christopher W. Hughes (eds.) Globalizations, Political Violence and Translation. New York, Palgrave Macmillan

Venuti, Lawrence. 2004. The Translator's invisibility: A History of Translation, London and New York: Routledge. 